\title{
Studi Rekognisi Masyarakat Adat Di Amerika Dan Indonesia
}

\author{
Jasardi Gunawan \\ Prodi Ilmu Pemerintahan, Institut Ilmu Sosial Budaya Samawa Rea \\ Email Korespondensi: jasardiprbadiku467@gmail.com
}

\begin{abstract}
Abstrak. Dalam Undang-undang nasional, eksistensi masyarakat adat telah mendapatkan pengaturan tersendiri sebagai refleksi pemberlakukan pluralisme hukum di Indonesia. Dalam Undang-Undang Dasar 1945, pengakuan dan penghormatan terhadap masyarakat adat tercantum dalam pasal 18B ayat (2), pasal 28 I ayat (3). Dalam tingkatan undang-undang, eksistensi masyarakat hukum adat diatur dalamUndang-undang No.5 Tahun 1960, Pasal 6 Undang-undang No. 39 tahun 1999, Undang-Undang No. 41 tahun 1999, Undang-undang otonomi daerah No. 32 Tahun 2004, Undang-undang No.7 Tahun 2004, Undang-undang No. 4 Tahun 2009 dan Undangundang No. 6 Tahun 2014. Melihat pengaturan rekognisi masyarakat adat mengharuskan adanya peraturan daerah atau Surat Keputusan Kepala Daerah sebagai syarat rekognisi masyarakat adat menunjukan sistem hukum yang berlaku adalah civil law syistem. Sementara itu di Amerika Serikat, masyarakat adat Navajo telah memiliki kewenangan untuk mengatur urusannya sendiri di dalam wilayahnya, khususnya terkait dengan hak atas sumberdaya alam. Terdapat dua kewenangan yang mereka miliki; Pertama, bagaimana mereka berwenang dalam mengeluarkan peraturan dalam mengontrol sumber daya alam mereka; dan kedua, bagaimana mereka memiliki hak untuk mendapatkan pembagian keuntungan yang adil atas sumber daya alam dan akuntabilitas untuk setiap pelanggaran yang terjadi di wilayah mereka. Melihat pengaturan rekognisi masyarakat adat di amerika yang menempatkan masyarakat adat pada ekstra konstitusi sehingga masyarakat adat mandiri dalam mengatur dirinya sendiri menunjukan sistem sistem hukum yang berlaku adalah ccommon law syistem
\end{abstract}

Kata Kunci : Rekognisi, Masyarakat Adat

\section{PENDAHULUAN}

Negaraterbentuk dan dibentuk berdasarkan sejarah tersendiri baik karena penyatuan diri beberapa daerah, pemisahan diri, atau karena bentukan negara jajahan. Indonesia terbentuk atas menyatunya daerah-daerah yang berbeda di seluruh Nusantara menjadi satu bangsa, satu bahasa dan satu tanah air. Daerah-daerah tersebut termasuk kesatuan masyarakat adat yang menjadi syarat mutlak berdirinya Negara Indonesia. Indonesia sebagai akumulasi dari kesatuan masyarakat adat dan daerah-daerah lain membentuk konstitusi sebagai hukum guna menjadi pijakan bernegara untuk menjaga, melindungi seluruh tumpah darah, memenuhi hak-hak konstitusional warga negaranya termasuk masyarakat adat.

Perwujudan pengaturan hak konstitusional masyarakat adat di Indonesia telah dimuat dalam Undang-Undang Dasar Negara Kesatuan Republik Indonesia Tahun 1945 (UUD NKRI 1945) dalam pasal 18B ayat (2) yang berbunyi " Negara mengakuai masyarakat hukum adat beserta hak-hak tradisionalnya sepanjang masih hidup dan sesuai dengan perkembangan masyarakat dan prinsip Negara Kesatuan Republik Indonesia, yang diatur dalam undangundang. Selain diatur dalam pasal 18B ayat (2) UUD NKRI 1945 juga diatur dalam, Pasal 28I ayat (3), Pasal 32 ayat (1) dan (2) UUD 1945. 
Sementara itu di Amerika Serikat, Dalam skema konstitusi di Amerika Serikat, masyarakat adat memiliki kedaulatan yang mandiri selain kedaulatan yang dimiliki pemerintah negara bagian dan federal. Saat ini, setidaknya terdapat 500 masyarakat adat yang secara bertahap melaksanakan kekuasaan mereka di bidang eksekutif, legislatif, dan yudikatif. Lebih penting lagi, masyarakat adat tidak diwajibkan untuk mematuhi Konstitusi Amerika Serikat dalam membangun model pemerintahan dan menentukan hukum yang berlaku bagi mereka karena mereka merupakan pihak extraconstitutional.

\section{METODE PENELITIAN}

Metode penelitian yang digunakan dalam penelitian ini adalah penelitian normative dengan menkaji teks peraturan perundang-undangan terkait dengan objek yang diteliti dengan menggunakan pendekatan statute approach, Conseptual appraoch dan comparative approach.

\section{HASIL DAN PEMBAHASAN}

\section{Sistem hukum Indonesia dalam Rekognisi Masyarakat Adat}

Posisining rekognisi hak masyarakat hukum adat dalam Sistem hukum Indonesia yang diatur dalam Konstitusi yang saat ini masih berlaku sebagai amandemen terakhir tahun 1999-2002 yaitu UUD NRI 1945. Pasal 18B ayat (2) memuat pengaturan rekognisi hak masyarakat adat namun Konstitusi ini belum menjadikan Masyarakat adat sebagai subjek hukum yang berdaulat atas ruang hidup, sumber daya, dan identitasnya.

Upaya rekognisi hak masyarakat adat dalam dinamikanya terlihat putusan Mahkamah Konstitusi (MK) No 35/PUUX/ 2012 yang menyatakan teritorialisasi wilayah hutan adat sebagai hutan negara yang diatur dalam UU Nomor 41 Tahun
1999 tentang Kehutanan bertentangan dengan UUD NRI 1945. Para hakim Mahkamah Konstitusi mengakui bahwa untuk menentukan status hukum, MHA sebagai subyek hukum tidak mudah. Mengingat keanekaragaman hukum adat di Indonesia begitu kompleks. Menentukan parameter masyarakat hukum adat bagi suatu tempat belum tentu cocok bagi kesatuan masyarakat hukum adat lainnya. Karena itu, tidak mengherankan jika penentuan syarat-syarat formal masyarakat hukum adat perlu hati-hati.

Lebih dari empat belas (14) UU
Nasional bersifat sektoral telah memberikanjaminan yang sama akan pengakuan terhadap hak-hak tradisional MHA, termasukdi dalamnya hak ulayat tanah, hak ulayat air, hak ulayat hutan, hak ulayat atastempat mengembala, dan hak-hak tradisional lainnya. Misalnya, hak keturunan dangelar adat, hak milik benda-benda keramat atau regalia, hak cipta dan Hak AtasKekayaan Intelektual (HAKI) atas karya dan hak cipta adat. Adapun UU tersebutadalah UU No. 5 Tahun 1960 tentang Peraturan Dasar Pokok-pokok Agraria, UUNo. 4 Tahun 2009 tentang Pertambangan Mineral dan Batubara, UU No. 5 Tahun1990 tentang Konservasi Sumber Daya Alam Hayati dan Ekosistemnya, UU No. 7Tahun 2004 tentang Sumber Daya Air, UU No. 41 Tahun 1999 tentang Kehutanan,UU No 22 tahun 2001 tentang Minyak dan Gas Bumi, dan UU No 24 Tahun 2003tentang MK, UU No. 4 Tahun 2004 tentang Kekuasaan Kehakiman, UU No. 14 Tahun1985 tentang MA RI, dan UU No. 32 Tahun 2004 tentang Pemerintahan Daerah.Adapun hak-hak tradisional masyarakat adat adalah hak untuk menempati tanahulayat, menggembala, hak memiliki hutan adat, hak mengambil ikan di sungai ataudanau, hak mengambil kayu bakar, hak berburu. Selain 
itu, ada hak-hak yang terkaitdengan hak kesenian, melukis, memahat, dan hak atas keyakinan dan kepercayaan.

Meskipun perubahan kebijakan politik dan hukum terhadap pengembanganmasyarakat hukum adat telah terjadi, nasib masyarakat hukum adat sampai saat inibelum mengalami perubahan signifikan. Pertama, Pengakuan dan penghormatanterhadap masyarakat hukum adat sebagaimana diatur dalam Pasal 18B ayat (2) dan28I ayat (3) UUD 1945 belum dapat diimplementasikan, dan karena itu MHA belummemperoleh manfaat nyata. Kedudukan MHA yang bukan subyek hukum (legalstanding) bukan saja tidak memiliki kewenangan untuk menguasai sesuatu hak milik,tetapi juga mereka tidak dapat berperkara di pengadilan. Padahal, UU No. 24 Tahun2003 memberikan peluang pada MHA untuk dapat berperkara di MahkamahKonstitusi RI.

Kedua, ketidakjelasan kedudukan hukum MHA tersebut berakibat ketidakpastian hukum dan keadilan hukum tidak dapat diperoleh. Hak-hak konstitusionalMHA yang seharusnya dapat dimanfaatkan oleh warga masyarakat. Kondisi merekadalam bidang pendidikan, bidang kebudayaan, di bidang pelayanan kesehatan,dan bidang sosial ekonomi umumnya terbelakang. Ketika MHA memperjuangkanhak-hak konstitusional mereka akibat kebijakan ekonomi nasional seperti tanah-tanah adat mereka dikuasai oleh pemilik modal domestik dan asing tidak dapatdicegah. Kebijakan pembangunan nasional yang diselenggarakan di berbagai daerah,apakah karena pertambangan mineral gas, minyak dan batu bara lainnya, ataukahakibat tumpang tindih pengaturan antara tanah-tanah adat dengan pihak kehutanan,maka MHA yang terkalahkan. Padahal pengakuan dan penghormatan terhadapMHA, secara tekstual telah jelas diatur dalam UU sektoral. Dalam kasus konflikpertanahan, terdapat 1400 kasus sengketa agraria di Pengadilan Sumatera Barat taksatu pun pihak masyarakat adat dimenangkan. Sama halnya dengan tanah Hak UlayatNagari sekitar 100ha telah berpindah menjadi tanah Departemen Kehutanan.

DasSeinterlihat bahwa ketidakadilan dan marginalisasi terhadap MHA selama periode kekuasaan Presiden Soeharto. Berbagai isu seputar agraria yang diperbincangkaan: konflik perebutan sumber daya, privatisasi lahan, pengambilalihan tanah (land-grabbing), klaim-reclaiming dan sebagainya, dalam perkembangannya telah menyita perhatian gerakan sosial, intelektual organik dan pengamat baik dalam dan luar negeri. Dalam lima kasus gugatan MHA nyaris tidak satupun ada yang dikabulkan. Terkecuali ada kasus di Papua yang dikabulkan, tetapi hal itu lebih dikarenakan adanya penggantian legal standing dari MHA menjadi perseorangan. Situasi ini telah memperparah hubungan antara pemerintah pusat dan masyarakat hukum adat jika tidak memiliki kepastian hukum.

Konflik vertikal maupun horizontal terus terjadi karena rekognisi masyarakat adat tidak dilakukan secara penuh dan efektif sehingga tidak telihat moral etik dalam muatan rekognisi hak masyarakat adat dalam konstitusi. Menurut Muhammad dahlan bahwa rekognisi hak MHA yang efektif mengandung lima klasifikasi: rekognisi konstitusional atas perbedaan kultural (constitutional recognition of cultural diversity), rekognisi konstitusional atas hak menentukan nasib sendiri secara budaya (constitutional recognitionof cultural self determination), rekognisi konstitusional atas hukum adat (constitutional recognition of customary law), rekognisi konstitusional atas hak berpolitik (constitutional recognition of 
politicalrights), serta rekognisi konstitusional atas hak mengklaim dan berjuang untuk hak komunal atas tanah, teritori dan sumber daya alam (constitutional recognition of right to claim and fight for collective rights oflands, teritories, and natural resources).

Menurut Aidul Fitriciada Azhari, Rekognisi atau pengakuan tidak mengubah norma yang hidup di masyarakat, melainkan hanya menghormati dan melindungi norma yang sudah ada pada komunitas dan wilayah asalnya sesuai dengan asal usulnya. Penguatan atas sistem yang telah ada dalam masyarakat yang lebih diutamakan daripada membentuk sistem yang baru, ini menunjukan bahwa rekognisi lebih mengarah pada konservasi atau pelestarian tradisi yang sudah ada di dalam sistem kehidupan masyarakat. Dengan sisi yang lebih dalam Aidul Fitriciada Azhari, mengatakan bahwa:

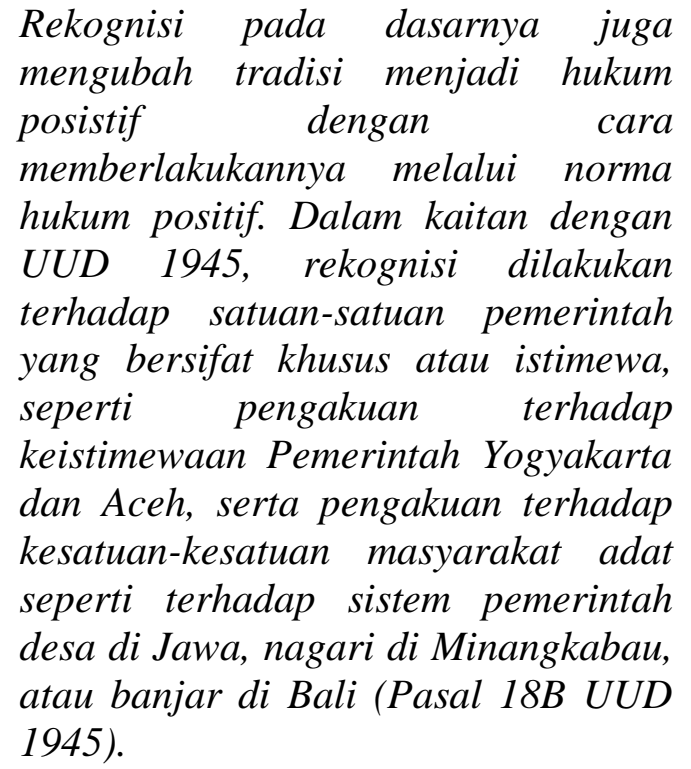

Kajian filsafat yang menonjol mengenai rekognisi diajukan oleh Hegel. Pentingnya penerapan politik pengakuan (politics of recognition) yang dapat menjadi landasan bagi terciptanya kebersamaan di antara berbagai budaya, kelompok etnis, ras dan agama. Sebab tak adanya pengakuan adalah penindasan (misrecognition is an oppression).

Teori hukum positif yang digunakan dalam penelitian ini berdasarkan pada sistem hukum dan sistem peraturan perundangundangan di Indonesia. Menurut Natabaya sistem hukum Indonesia adalah suatu rangkaian konsepsi atau pengertian hukum yang saling terkait dan tergantung, saling pengaruh-mempengaruhi, yang terdiri atas perangkat peraturan-peraturan perundangundangan, aparatur penegak hukum, dan kesadaran hukum atau budaya hukum masyarakat Indonesia yang salingterpadu (totalitas) yang unsur-unsurnya tidak dapat dipisahkan satu sama lainnya yang semuanya dilandasi oleh falsafah Pancasila dan UUD Negara Republik Indonesia Tahun1945.

Berdasarkan teori Honneth, politik rekognisi memiliki tiga ranah yang berbeda namun saling berkaitan: cinta, hukum/hak, dan solidaritas yang masing-masing memiliki konturnya sendiri beserta jenis ancaman yang berbeda pula. Di samping itu juga, dalam Perjanjian Westphalia 1648 selain mengakhiri Perang 30 tahun di daratan Eropa yang dipicu oleh Reformasi oleh Marthin Luther di Jerman, juga mengakhiri hegemoni politik Gereja Katholik Roma atas Negara-negara di Eropa dan berbagai belahan dunia lainnya. Perjanjian Westphalia mengedepankan dua hal penting yang berkembang di Eropa waktu itu: (i) pengakuan Negara bangsa sebagai entitas paling berdaulat di hadapan warga negaranya; dan bahwa (ii) Negara lain tidak berhak mencederai kedaulatan tersebut dalam sebuah sistem internasional.

Dalam konstitusi mengatur rekognisi hak masyarakat adat dengan pendekatan :

1. Pendekatan tata pemerintahan (pasal 18B ayat (2))

Secara Konstitusioal pengaturan masyarkat adat sebelum amandemen 
sering berdasar pada Penjelasan UUD 1945 Pasal 18 angka II yang berbunyi:

"Dalam territoir Negara Indonesia terdapat lebih kurang 250 zelfbesturende landchappen dan volksgetneenschappen, seperti desa di Jawa dan Bali, negeri di Minangkabau, dusun dan marga di Palembang dan sebagainya. Daerahdaerah itu mempunyai susunan asli, dan oleh karenanya dapat dianggap sebagai daerah yang bersifat istimewa. Negara Republik Indonesia menghormati kedudukan daerah-daerah istimewa tersebut dan segala peraturan negara yang mengenai daerah-daerah itu akan mengingati hak-hak asal-usul daerah tersebut."

Dalam UUD NRI 1945 Pasal 18B ayat (2) merujuk kepada kesatuankesatuan masyarakat adat yang secara kelembagaan merujuk pada desa, nagari, dusun, marga atau bentuk lainnya. Oleh karena itu, pembicaraan mengenai masyarakat adat dalam tulisan ini adalah membicarakan masyarakat adat yang dimaksud dalam Pasal 18B ayat (2) UUD 1945 Pasal 18B ayat (2) UUD 1945 sebagai salah satu landasan konstitusional masyarakat adat menyatakan pengakuan secara deklaratif bahwa negara mengakui dan menghormati keberadaan dan hakhak masyarakat adat. Pasal 18B ayat (2) berbunyi :

"Negara mengakui dan menghormati kesatuan-kesatuan masyarakat hukum adat beserta hak-hak tradisionalnya sepanjang masih hidup dan sesuai dengan perkembangan masyarakat dan prinsip Negara Kesatuan Republik Indonesia, yang diatur dalam undang-undang. "

Pengakuan tersebut memberikan batasan-batasan atau persyaratan agar suatu komunitas dapat diakui keberadaan sebagai masyarakat adat. Ada empat persyaratan keberadaan masyarakat adat menurut Pasal 18B ayat (2) UUD 1945 antara lain:

a. Sepanjang masih hidup

b. Sesuai dengan perkembangan masyarakat

c. Prinsip Negara Kesatuan Republik Indonesia

d. Diatur dalam undang-undang

2. Pendekatan HAM (pasal 28i (1) dan (2))

Pengaturan terkait hak-hak masyarakat adat diatur dalam Pasal 28I ayat (3) berbunyi:

"Identitas budaya dan hak masyarakat tradisional dihormati selaras dengan perkembangan zaman dan peradaban."

Secara substansial, pola materi muatan dari Pasal 28I ayat (3) ini hampir sama dengan materi muatan Pasal 6 ayat (2) UU No. 39 Tahun 1999 tentang Hak Asasi Manusia (UU HAM) yang berbunyi: "Identitas budaya masyarakat hukum adat, termasuk hak atas tanah ulayatdilindungi, selaras dengan perkembangan zaman." UU HAM lahir satu tahun sebelum dilakukannya amandemen terhadap Pasal 28I ayat (3) UUD 1945. Kuat dugaan, Pasal 28I ayat (3) UUD 1945 dan juga beberapa ketentuan terkait hak asasi manusia lainnya di dalam konstitusi mengadopsi materi muatan yang ada di dalam UU HAM.

Namun ada sedikit perbedaan antara Pasal 28I ayat (3) UUD 1945 dengan Pasal 6 ayat (2) UU HAM. Pasal 6 ayat (2) UU HAM mengatur lebih tegas dengan menunjuk subjek masyarakat hukum adat dan hak atas tanah ulayat. Sedangkan Pasal 28I ayat (3) membuat rumusan yang lebih abstrak dengan menyebut hak masyarakat tradisional. 
Hak masyarakat tradisional itu sendiri merupakan istilah baru yang sampai saat ini belum memiliki definisi dan batasan yang jelas. Pasal 28I ayat (3) UUD 1945 juga mempersyaratkan keberadaan dan hak-hak masyarakat adat sepanjang sesuai dengan perkembangan zaman. Pendekatan konstitusional terhadap Pasal 28I ayat (3) UUD 1945 ini adalah pendekatan HAM. Hal ini nampak jelas dalam sistematika UUD 1945 yang meletakkan Pasal 28I ayat (3) UUD 1945 di dalam Bab XA tentang Hak Asasi Manusia bersamaan dengan hak-hak asasi manusia lainnya. Oleh karena itu, instansi pemerintah yang paling bertanggungjawab dalam landasan konstitusional ini adalah Kementerian Hukum dan HAM serta Komisi Nasional Hak Asasi Manusia.

3. Pendekatan Kebudayaan (pasal 31 (2))

Dalam konstitusi yang berkaitan dengan keberadaan dan hak-hak masyarakat adat adalah Pasal 32 ayat (1) dan ayat (2) UUD 1945 yang berbunyi: Pasal 32 ayat (2)

"Negara memajukan kebudayaan nasional Indonesia di tengah peradaban dunia dengan menjamin kebebasan masyarakat dalam memelihara dan mengembangkan nilai-nilai budayanya."

Pasal 32 ayat (2)

"Negara menghormati dan memelihara bahasa daerah sebagai kekayaan budaya nasional."

Kedua ketentuan ini tidak terkait langsung dengan hak masyarakat adat atas sumber daya alam. Namun dalam kehidupan keseharian masyarakat adat, pola-pola pengelolaan sumber daya alam tradisional sudah menjadi budaya tersendiri yang berbeda dengan pola-pola yang dikembangkan oleh masyarakat industri. Pola-pola pengelolaan sumber daya alam inilah yang kemudian menjadi salah satu kearifan lokal atau kearifan tradisional masyarakat dalam pengelolaan sumber daya alam dan lingkungan hidup.

Ketentuan ini menjadi landasan konstitusional dalam melihat masyarakat dari dimensi kebudayaan. Hak yang diatur dalam ketentuan ini yaitu hak untuk mengembangkan nilai-nilai budaya dan bahasa daerah. Tidak dapat dipungkiri bahwa pendekatan kebudayaan dalam melihat adat istiadat dari masyarakat adat menjadi pendekatan yang paling aman bagi pemerintah karena resiko pendekatan ini tidak lebih besar dibandingkan dengan pendekatan lainnya.

Rekognisi konstitusional atas perbedaan kultural (constitutional recognitionof cultural diversity). Klasifikasi ini menuntut adanya pengakuan terhadap keragaman budaya oleh negara sebagai elemen struktural dari sistem sosial politik seperti Bolivia yang mendefinisikan dirinya sebagai negara plurinasional. Tiap MHA memiliki otonominya masing -masing dan tidak ada satupun dalih yang membenarkan tindakan hukum dari negara untuk mengenyampingkan otonomi tersebut kecuali melalui proses yang demokratis dan terbuka.

Dalam konstitusi tidak mengatur rekognisi hak masyarakat adat dengan pendekatan :

1. Pendekatan Sumber daya Alam

Rekognisi konstitusional atas hak mengklaim dan berjuang untuk hak komunal atas tanah, teritori dan sumber daya alam (constitutional recognitionof right to claim and fight for collective rights of lands, teritories, and natural resources). 25 Rekognisi ini dipandang empat sarjana tersebut sebagai elemen paling penting 
di era kontemporer karena segala macam bentuk pelanggaran hak asasi manusia terhadap klasifikasi kelima akan meluas pada aspek rekognisi lainnya.

2. Pendekatan Hukum adat

Rekognisi konstitusional atas hukum adat (constitutional recognition of customary law). Klasifikasi ini pertama-tama menuntut adanya pengakuan hukum adat sebagai hukum yang memiliki kekuatanotoritarif bagi masyarakat dalam sudut pandang negara dan keduarekognisi ini menurut adanya perombakan hukum besarbesaranke arah pluralisme hukum (dalam tradisi hukum Amerika Latin disebut derechos consetudinarios). Rekognisi ini akan membebaskan MHAterhadap pilihan hukum; membebaskan mereka untuk membangunsistem peradilan prakolonial maupun sistem sanksi yang pernah ada(tetapi dengan syarat bahwa sanksi yang diberikan tidak merengguthak hidup orang lain seperti tradisi persembahan) dan mekanismeresolusi konflik secara adat.

Dalam Undang-Undang sektoral yang salah satunya mengatur rekognisi masyarakat adat adalah Undangundang nomor 41 Tahun 1999 Tentang Kehutanan Pasal 67 ayat (2) yang berbunyi "Pengukuhan keberadaan dan hapusnya masyarakat hukum adat sebagaimana dimaksud dalam ayat (1) ditetapkan dengan Peraturan Daerah. dengan adanya ketentuan tersebut sudah banyak peraturan daerah yang mengukuhkan dan mengatur masyarakat adat misalnya Peraturan Daerah Kabupaten Paser Nomor 4 Tahun 2019 Tentang Pengakuan dan Perlindungan Masyarakat Hukum adat. Pengaturan Rekognisi mayarakat adat dengan peraturan daerah dikuatkan dengan putusan Mahkamah konstitusi Nomor 35/PUUIX/2012 bahwa "pengaturan yang ditetapkan dengan Peraturan Pemerintah dan Peraturan Daerah dapat dibenarkan sepanjang peraturan tersebut menjamin kepastian hukum yang berkeadilan".

Mengkaji bentuk pengaturan rekognisi masyarakat adat diatas baik yang diatur dalam konstitusi dan aturan turunannya menunjukan bahwa sistem hukum Indonesia dalam rekognisi masayrakat adat menganut sistem hukum civil law syistem karena masyarakat adat baru diakui ketika diatur oleh undang-undang untuk menjamin kepatian hukum. Namun Pada prakteknya pengakuan masyarakat adat tidak selalu dengan peraturan Daerah kabupaten atau daerah provinsi seperti pengakuan masyarakat adat cek bocek, Talonang, dan Pekasa dalam Inkuiri Nasional Komnas Ham tahun 2014, Pemerintahan Desa ongko kabupaten sumbawa "mengakui ketua adat ()masyarakat adat sebagai penyelesaian sengketa atau hakim perdamaian. "dikabulkannya edy kuswanto sebagai anggota masyarakat adat pekasa, Sumbawa, NTB sebagai pemohon dalam Uji materi UUP3H, diakuinya wilayah adat Talonang oleh camat Sekongkang, KSPH, Kepala Desa Talonang dan pada tahun 2019 Diakuinya Rencana Tata Ruang wilayah adat Talonang oleh kepala Desa dan BPD Desa Talonang, diakui keberadaan "tanah panising" (tanah warisan turun temurun atau tanah adat oleh nyaka (kepala suku)) di bakalewang kanar, Sumbawa. 


\section{Sistem Hukum Amerika dalam Rekognisi Masyarakat adat \\ Dalam skema konstitusi di Amerika} Serikat, masyarakat adat memiliki kedaulatan yang mandiri selain kedaulatan yang dimiliki pemerintah negara bagian dan federal. Saat ini, setidaknya terdapat 500 masyarakat adat yang secara bertahap melaksanakan kekuasaan mereka di bidang eksekutif, legislatif, dan yudikatif. Lebih penting lagi, masyarakat adat tidak diwajibkan untuk mematuhi Konstitusi Amerika Serikat dalam membangun model pemerintahan dan menentukan hukum yang berlaku bagi mereka karena mereka merupakan pihak extraconstitutional.

Sebagai contoh, sesuai dengan Perjanjian pada tahun 1866 antara Pemerintah Federal Amerika Serikat dan Cherokee Nation, Mahkamah Agung Amerika Serikat dalam kasus Cherokee Nation v. Journeycake, menyatakan bahwa tanah dan wilayah yang tunduk pada perjanjian adalah milik bersama semua masyarakat adat Cherokee dan mereka memegang hak penuh atas segala properti yang berada di wilayah mereka. Dengan demikian, kedudukan mereka terpisah dari pemerintah federal dan pemerintah negara bagian. Skema ini menunjukkan bahwa pemerintah adat merupakan pemerintahan tersendiri dan menciptakan hubungan antara pemerintahan adat dan pemerintah federal sebagai hubungan government to government."

Dalam menjalankan kekuasaannya, sebagian besar masyarakat adat di Amerika Serikat telah memiliki konstitusi formal dan peraturan-peraturan lain yang memberikan kewenangan untuk melaksanakan yurisdiksi atas berbagai kegiatan di dalam wilayah mereka, termasuk tindak pidana, hubungan hukum privat, dan perpajakan. Salah satu masyarakat adat paling berpengaruh di Amerika Serikat adalah Navajo. Mereka merupakan masyarakat adat terbesar dari semua suku asli di Amerika Serikat. Mereka tersebar di 27.000 mil persegi, meliputi wilayah tenggara Utah, wilayah timur laut Arizona, dan wilayah barat laut New Mexico. Dalam sejarahnya, Navajo didirikan sebagai wilayah berdaulat melalui Perjanjian antara masyarakat Navajo dan Pemerintah Federal Amerika Serikat di tahun 1868. Pada dasarnya, masyarakat Navajo telah lama memiliki struktur pemerintahan tersendiri, namun penemuan minyak dan sumber daya alam lainnya di wilayah Navajo di awal abad ke-20 mengharuskan mereka untuk membentuk pemerintahan Navajo yang lebih terstruktur dan berkelanjutan. Pada tahun 1923, struktur pemerintahan formal masyarakat Navajo telah diakui oleh Amerika Serikat. Pengakuan ini dilakukan untuk memberikan ha katas pengelolaan atas sumber daya alam mengingat di wilayah Navajo terdapat perusahan-perusahaan minyak dan pertambangan. Selain itu, batu bara yang terdapat di wilayah Navajo telah menghasilkan pendapatan yang besar bagi masyarakat Navajo.

\section{Pengaturan Rekognisi Hak atas Sumber Daya Alam bagi Masyarakat Adat Navajo di Amerika Serikat}

Bagian ini akan menjelaskan bagaimana masyarakat adat Navajo memiliki kewenangan untuk mengatur urusannya sendiri di dalam wilayahnya, khususnya terkait dengan hak atas sumberdaya alam. Terdapat dua parameter bagaimana mereka dapat menggunakan hak sumber daya alamnya. Pertama, bagaimana kewenangan mereka dalam mengeluarkan peraturan dalam mengontrol sumber daya alam mereka; kedua, bagaimana mereka memiliki hak untuk mendapatkan pembagian keuntungan yang adil atas sumber daya alam dan akuntabilitas untuk 
setiap pelanggaran yang terjadi di wilayah mereka.

\section{a. Peraturan Masyarakat Adat Navajo Indian}

Dalam pengeluaran peraturan, masyarakat adat Navajo telah mengeluarkan beberapa peraturan diantaranya the Air Pollution Prevention and Control Act, the Clean Water Act, dan the Solid Waste Act.

1) Navajo Nation Air Pollution Prevention and Control Act

Mengingat potensi polusi udara yang ditimbulkan dalam kegiatan pemanfaatan sumber daya alam, masyarakat adat Navajo telah mengeluarkanThe Navajo Nation's Air Pollution Prevention and Control Act("NN APPCA"). Tujuan dari tindakan ini adalah untuk mengontrol tingkat polusi udara di wilayah adat Navajo. Hal ini dilakukan untuk menjamin kesehatan, keselamatan dan kesejahteraan umum dari semua masyarakat Navajo, dan segala asset yang menyertainya termasuk kehidupan tumbuhan dan hewan di wilayah Navajo.

Selain itu, NN APPCA mengharuskan pemerintah Navajo untuk membuat laporan berkaladari kualitas udara sehingga akan dapat mengetahui wilayah yang memiliki tingkatpolusi udara tertinggi di wilayah Navajo. Setiap proyek-proyek baik pemerintah atau swasta yang dapat memiliki dampak besar pada kualitas udaraharus melengkapi persyaratan tingkat polusi udara yang diperkenankan oleh NN APPCA.

Mekanisme penegakan hokum juga terdapat dalam NN APPCA. Hal ini terjadi ketika Direktur Eksekutif Navajo Nation of the Environmental Protection Agency Navajo
Nation("Direktur") menyimpulkan bahwa NNAPPCA telah dilanggar, Direktur dapat mengeluarkan beragam tindakan meliputi:

a) Mengeluarkan perintah untuk mematuhi NN APPCA

b) Mengeluarkan sanksi administratif

c) Mengajukan gugatan perdata

d) Pengajuan tindak pidana.

2) Navajo Nation Clean Water Act

Mengingat hubungan yang erat antara pembangunan sumber daya alam, terutama untuk keperluan energi, dan penggunaan air, masyarakat Navajo telah mengeluarkanClean Water Act("NN CWA").Peraturan ini menyatakan bahwa pelepasan bahanbahan polutan ke perairan Navajo oleh perusahaan industri, dan ketidaktepatan manajemen pengelolaan limbah, berpotensi membahayakan kesehatan, kesejahteraan, dan lingkungan masyarakat Navajo.

a) Hal yang menarik, di dalam Pasal 1311 disebutkan bahwa standar kualitas air harus dirancang untuk melindungi "nilai budaya" yang dimiliki oleh masyarakat Navajo dalam pengelolaan air.Hal ini disebabkan karena air memiliki nilai khsusu bagi masyarakat Navajo yang mencakup dimensi budaya dan spiritual.

Sama dengan NN APPCA, NN CWA juga menyiapkan mekanisme penegakan hokum yang meliputi:
a. perintah kepatuhan
b. sanksi administrasi
c. gugatan perdata.
d. tuntutan pidana.

3) Navajo Nation Tindakan Limba Padat Suku Navajo Indiantelah memberlakukanNavajo Nation Solid 
Waste Act(NN SWA) yang mendefinisikan waste" as "any garbage, refuse or sludge from a wastewater treatment plant, water supply treatment plant or air pollution control facility and other discarded material, including solid, liquid, semisolid, or contained gaseous material resulting from residential, industrial, commercial, mining, and agricultural operations and from community activities.

NNSWA menyatakan bahwa pembuangan sampah di atas dan di dalam tanah tanpa perencanaan dan pengelolaan yang cermat dapat menghadirkan bahaya bagi kesehatan masyarakat dan lingkungan hidup.NN SWA juga menyediakan berbagai metode penegakan hukum melalui perintah kepatuhan, sanksi administrasi, gugatan perdata, dan penegakan hukum pidana.

\section{Hakatas Pembagian Manfaat yang Setara dan Akuntabilitas atas Pelanggaran}

Masyarakat adat Navajo memiliki peran penting dalam perencanaan, pengelolaan dan pengawasan sumber daya alam yang ditemukan di wilayah mereka, termasuk melaksanakan kekuasaan untuk mengeluarkan sewa atau izin, dan menetapkan tarif untuk sewa dan royalti, serta berbagai manfaat lain yang diperoleh dari eksploitasi sumber daya alam. Selain itu, mereka memiliki legal standinguntuk melakukan proses penuntutan ataupun gugatan terhadap pemerintah Amerika Serikat apabila terdapat pelanggaran komitmen khususnya apabila merekamenganggap pemerintah federal Amerika Serikat tidak memberikan porsi keuntungan yang adil dan merata atas pemanfaatan sumber daya alam di wilayah masyarakat adat Navajo.

\section{KESIMPULAN}

Dalam Undang-undang nasional, eksistensi masyarakat adat telah mendapatkan pengaturan tersendiri sebagai refleksi pemberlakukan pluralism hukum di Indonesia. Dalam Undang-Undang Dasar 1945, pengakuan dan penghormatan terhadap masyarakat adat tercantum dalam pasal 18B ayat (2), pasal 28 I ayat (3). Dalam tingkatan undang-undang, eksistensi masyarakat hukum adat diatur dalamUndang-undang No.5 Tahun 1960, Pasal 6 Undang-undang No. 39 tahun 1999, Undang-Undang No. 41 tahun 1999, Undang-undang otonomi daerah No. 32 Tahun 2004, Undang-undang No.7 Tahun 2004, Undang-undang No. 4 Tahun 2009 dan Undang-undang No. 6 Tahun 2014. Melihat pengaturan rekognisi masyarakat adat mengharuskan adanya peraturan daerah atau Surat Keputusan Kepala Daerah sebagai syarat rekognisi masyarakat adat menunjukan sistem hukum yang berlaku adalah civil law syistem.

Sementara itu di Amerika Serikat, masyarakat adat Navajo telah memiliki kewenangan untuk mengatur urusannya sendiri di dalam wilayahnya, khususnya terkait dengan hak atas sumberdaya alam. Terdapat dua kewenangan yang mereka miliki; Pertama, bagaimana mereka berwenang dalam mengeluarkan peraturan dalam mengontrol sumber daya alam mereka; dan kedua, bagaimana mereka memiliki hak untuk mendapatkan pembagian keuntungan yang adil atas sumber daya alam dan akuntabilitas untuk setiap pelanggaran yang terjadi di wilayah mereka. Melihat pengaturan rekognisi masyarakat adat di amerika yang menempatkan masyarakat adat pada ekstra konstitusi sehingga masyarakat adat mandiri dalam mengatur dirinya sendiri menunjukan 
sistem sistem hukum yang berlaku adalah ccommon law syistem.

\section{SARAN}

Dibutuhkan undang-undang khusus yang mengatur tentang Pengakuan, Perlindungan masyarakat adat guna untuk bisa meminimalisir terjadinya ketidak adilan dan marjinalisasi terhadap harkat dan martabat masyarakat adat. sehingga dengan adanya undang-undang khusus tentang pengakuan dan perlindungan, masyarakat adat bisa mencapai hak-haknya.

Format Tabel

Table 1. kriteria validitas instrument pengetahuan metakognisi berdasarkan rata-rata nilai validator

\begin{tabular}{|ll|}
\hline Interval Nilai & kriteria \\
\hline$>3,6$ & Sangat Valid \\
\hline $2,8-3,6$ & Valid \\
\hline
\end{tabular}

\section{DAFTAR PUSTAKA}

Anaya, S,( 1996), Oxford University Press, Indigenous Peoples in International Law

An-Naim, (2007), Bandung: Mizan, Abdullahi Ahmed, Islam dan Negara Sekuler: Menegosiasikan Masa Depan, Syariah,

Arizona, Yance, Antara Teks dan konteks: Dinamika pengakuan hukum terhadap hak masyarakat adat atas sumber daya alam di Indonesia.

Dahlan, Muhammad, Undang : Jurnal Hukum, Vol. 1 No. 2 (2018), Rekognisi Hak Masyarakat Hukum Adat dalam Konstitusi "Fakultas Hukum Universitas Brawijaya.

Kleden ,Emil, hasil penelitian Asep Yunan Firdaus 2007 (Kompas, 10 Agustur 2007)
Fishman, Shammai, "Fiqh al-Aqalliyat: A Legal Theory for Muslim Minorities", (Hodson Institute: Research Monograph on the Muslim World, Series No. 1, Paper No. 2, October 2006), dalam Dr. Ahmad Imam Mawardi, Fiqh Minoritas,.

Hasanah , Siti, Potret Integritas moral wakil rakyat indonesia: Studi Terhadap Penegakkan Kode etik DPR RI, Dalam Transendensi Hukum prospek dan implementasi. Genta publishing. Yogyakarta

Kuntowidjoyo, Islam sebagai ilmu.: Efistimologi, metodelogi, dan etika. Yogyakarta. Tiara wacana. 2006.

Mahfud MD dkk, dalam suatu Seminar Nasional, Hukum dan Hukum Adat di Dalam Sistem Ketatanegaraan RI. Kencana Suluh. Senin 01 Maret 2010.

Mahmashani, Subhi, Falsafah al-Tasyri' $f i$ al-Islam, Dar al-'Ilm li al-Malayiin, Beirut, cet. V, hlm.220-223, (http://huseinmuhammad.net/huku m-islam-yang-tetap-dan-yangberubah/\#sth ash.p376gTz7.dpuf), akses 26 Novemver 2019

Mawardi, Ahmad Imam, MA, Fiqh Minoritas: Fiqh Al-Aqalliyyat dan Evolusi Maqasid al-Syari'ah dari Konsep ke Pendekatan, (Yogyakarta: LkiS Group, 2012),

Nasir, Gamal abdul, Mengawal Pengakuan dan eksistensi hak ulayat.taah ulayat masyarakat hukum adat, dalam Hukum Transedental Pengembangan dan Penegakkan Hukum di Indonesia. Genta Publishing., Yogyakarta.

Porta , Della dkk, Approaches and Methodologie in the Social 
Sciences, Cambridge University Press, 2008. hlm. 171.

Prabowo, Rian Adhivira, Politik Rekognisi Axel Honneth: Relevansinya terhadap Jaminan Kesetaraan dalam Hukum di Indonesia. Jurnal Ilmu Pemerintahan, Vol. 4, No. 2, 2019.

Simarmata dan Rikardo 2006 Pengakuan hukum terhadap masyarakat adat di Indonesia. Jakarta: UNDP. Hal. 209)

Thontowi, Jawahir dkk, Aktualisasi Masyarakat Hukum Adat (MHA): Perspektif Hukum dan Keadilan Terkait Dengan Status MHA dan Hak-hak Konstitusionalnya, Pusat Penelitian dan Pengkajian Perkara, Pengelolaan Teknologi Informasidan Komunikasi Mahkamah Konstitusi Republik Indonesia, bekerjasama denganCentre for Local Law Devolepment Studies (CLDS) Fakultas Hukum Universitas Islam Indonesia,

Gloria Valencia Weber, Tribal Courts: Custom and Innovative Law, The New Mexico Law Review Vol. 24 (1994),

Yurisprudensi dalam Kasus di Mahkamah Agung Amerika Serikat pada kasus Santa Clara Pueblo v. Martinez, (1978),

Yurisprudensi dalam Kasus di Mahkamah Agung Amerika Serikat pada kasus Cherokee Nation v. Journeycake, (1894),

Royster V. Judith , Climate Change and Tribal Water Rights: Removing Barriers to Adaptation Strategies, in Randall S. Abate \& Elizabeth Ann Kronk eds.,Climate Change and Indigenous Peoples:The Search for Legal Remedies(Cheltenham:
Edward Elgar Publishing Limited, 2013)

Navajo Tourism Departement, The History of Cowboys and Indians, DISCOVER NAVAJO, http://discovernavajo.com/Cowboy s\%20\&\%20Indians-1.pdf. diakses pada 30 Juli 2020 